\title{
A Study of the Concession Speech by President Goodluck Jonathan
}

\author{
Adaobi Ngozi Okoye \& Benjamin Ifeanyi Mmadike \\ http://dx.doi.org//10.4314/ujah.v17i1.8
}

\begin{abstract}
When language is used to communicate to an audience, the listeners are given an insight into the intention of the speaker. This study analyses the concession speech made by President Goodluck Jonathan. It adopts the speech act theory in the classification of the illocutionary acts which are contained in the speech. The simple percentage is used in computing the frequency of the various illocutionary acts. Our findings show a preponderance of the representative speech act and the absence of the directive.
\end{abstract}

\section{Introduction}

Political discourse has in recent times attracted the interest of researchers hence the role of language in politics and political speeches have been investigated by researchers (Akinwotu, (2013), Waya David (2013) and Hakansson (2012)) . A political speech is seen as a highly guarded form of speech when compared to a commercial speech. Its guarded form is due to its expressive nature and its importance. Speeches are made by politicians as a means of conveying information and opinion to the audience. Usually, these speeches are written in advance by professional speech writers. They are written to be spoken as if not written. In transmitting most of these political speeches via the social networks, it is often the case that highlights of the speeches ,referred to as sound bites, are transmitted. These speeches which are usually communicated through language could be in the form of a campaign speech made before the elections, 
acceptance of nomination speech made after the party's primaries, concession speech made by a candidate who lost an election or an inaugural speech delivered by the candidate who won an election during his swearing in to the elected office.

These different speeches have caused attention to shift from language form to language function, that is, attention is focused on what people do when they use language. As pointed out by Akinwotu (2013) political communication involves a focus on meaning, the understanding of which is largely a function of reading the illocutionary force of a speaker's utterance. In politics, a concession entails a situation where a losing candidate in an election publicly yields to a winning candidate after the election, when the final results have been made clear. Usually the concession speech of the candidate precedes the acceptance speech of the winning candidate. In this paper, our focus is on the concession speech of President Goodluck Jonathan, delivered on the $31^{\text {st }}$ day of March, 2015. Our intention is to examine the classes of illocutionary acts obtainable in the speech. The concession speech is significant because it is the first of its kind in the history of Nigeria. In addition, it is an ice breaker in that the concession saved the lives of Nigerians. This follows from the remark by Gen. Buhari to Goodluck Jonathan during the handover when the former told the latter thus: "If you had attempted to make things difficult, it could have been at the expense of the lives of poor Nigerian...." (Daily Sun Friday 29 May, 2015, Pg. 8). Furthermore, the concession earned President Goodluck a special place in the history of the country. Hence, he is described as the steward of peace, democracy and national development by fellow Nigerians and world leaders.

\section{Studies on Political Speech Act}


Akinwotu (2013) investigates the speech acts contained in the acceptance of nomination speeches of Chief Obafemi Awolowo and Chief MKO Abiola. The study reveals that the acceptance speeches are characterized by illocutionary acts which are used to achieve persuasion. In addition, the study also claims that there is the preponderance of assertive, expressive and commissive acts that are mostly used as mobilization strategies, especially during political campaigns when it is inevitable for candidates to persuade their listeners in order to win the election.

Waya (2013) adopts the speech act theory in the analysis of President Goodluck's victory and inaugural speeches. He claims that the political speeches are composed primarily of assertive sentences. Furthermore, the author avers that the political speeches reveal that political leaders perform various speech acts through their speeches. These are usually set up as a guide in evaluating the sincerity and functionality of their administrative policies. Using a combination of speech acts and rhetorics, Adetunji (2009) in Akinwotu (2013) studies the speech acts and rhetorics contained in the second inaugural speeches of President Olusegun Obasanjo of Nigeria and President George Bush of America. The finding reveals that two speeches belonging to the same discourse genre may not have the same illocutionary force and rhetorics.

Hakansson (2012) explores the use of personal pronouns in the state of the union speeches held by two American Presidents and indicates that the pronominal choices of the Presidents do not differ significantly. Furthermore, the study claims that the pronoun ' $\mathrm{I}$ ' is used when the speaker wants to speak as an individual rather than as a representative of a group. In addition, Hakansson opines that the pronoun 'they' is used to separate self from others while 'we' is used to invoke a sense of collectivity and shared 
responsibility. Other findings of the study indicate that these usages vary depending on the context of the speech.

\section{Theoretical Framework}

The theoretical framework adopted for the study is the speech act theory propounded by J.L Austin (1962) and developed by J. R Searle (1969, 1975, 1976ff). Austin's work represents a reaction to some attitudes to language summarized by Saeed (2007:223) as follows:

- the basic sentence type in language is declarative, (that is statement or assertion).

- the primary use of language is to describe state of affairs using statements.

- the meaning of utterance can be described in terms of their truth or falsity.

According to Levinson (1983:326) and Saeed (2003:227), Austin proposes that communicating speech acts involves three elements; the speaker says something, the speaker signals an associated speech act, and the speech act causes an effect on her listeners. These three kinds of acts as distinguished by Austin are outlined as follows;

- Locutionary Act - It is simply the activity we engage in when we say something (Mey 2001).

- Illocutionary Act - This involves the making of a statement, offer, promise etc in uttering a sentence by virtue of the conventional force associated with it (or with its explicit performative paraphrase).Thus, an illocutionary act is usually associated with a certain force referred to as the illocutionary force. The term speech acts is often used with this meaning of illocutionary acts, i.e performing an act by uttering a sentence. 
-Perlocutinary Act - This is concerned with what follows an utterance: the effect or 'take up' of an illocutionary act. Searle (1976) proposes five basic kinds of actions that one can perform in speaking. The basic kinds are listed as follows;

i. Representatives or Assertives, commit the speaker to the truth of the expressed proposition. These acts involve such cases as stating, concluding and reporting.

ii. Directives, attempt to get the addressee to do something. Instances of this speech act type include requesting, demanding and questioning

iii. Expressives, express a psychological state such as thanking, apologizing, congratulating and welcoming. iv. Commissives, commit the speaker to some future course of action such as pronouncing, offering and threatening.

v. Declaratives, speech acts which effect immediate changes in the institutional state of affairs. This act includes such instances as christening, excommunicating, dismissing and accepting.

These five illocutionary acts represent whatever intention a speaker may wish to achieve through his utterances and they are adopted in our analysis.

\section{Methodology}

The data for this study is the concession speech of President Goodluck Jonathan. It was retrieved from the internet (http/daily post.ng/2015/Nigeria decides full text of President Jonathan concession). The concession speech comprises twenty-one (21) sentences labeled Extracts 1-21. These extracts are classified based on the illocutionary acts they express. In computing the percentage of each illocutionary act, the simple percentage is used. The formulae employed is 
$\frac{\text { NO of Illocutionary act }}{\text { Total No of Extracts }} \times \frac{100}{1}$

The results based on the percentages are further displayed on a pie chart for clarity.

\section{Data Presentation/Analysis}

Representatives / Assertives: This kind of speech act commits the speaker to the truth of the expressed proposition. These acts involve such cases as stating, concluding and reporting as shown in the following extracts in example 1

1.Extract 2: I promised the country free and fair elections Extract 3: I have kept my word

Extract 4: I have also expanded the space for Nigerians to participate in the democratic process. That is one legacy I will like to see endure.

Extract 6: As I have always affirmed, nobody's ambition is worth the blood of any Nigerian.

Extract 7: The unity, stability and progress of our dear country is more important than anything else.

Extract 11: Today, the PDP (Peoples' Democratic Party) should be celebrating rather than mourning.

Extract 12: For the past 16 years, we have steered the country away from ethnic and religious politics.

Extract 14: We erected a pan-Nigerian political party and brought home to our people the realities of economic development and social transformation.

Extract 15: Through patriotism and diligence, we have built the biggest and most patriotic party in Nigerian history.

Extract 19: I have conveyed my personal best wishes to General Muhammadu Buhari.

In the assertive, there are a total of eleven (11) extracts. From extract 2 through 7 , the speaker simply states a proposition that has a truth condition. In other words, he is 
committed to the truth of the statement made. The extracts represent a paradigm case of statements. We also notice that the assertive in extract 4 is followed by what may be seen as a wish by the speaker. Extract 19 can be seen as a case of reporting. The speaker in saying I have conveyed my personal best wishes to General Muhammadu Buhari engages in what appears to be a report given to the listener on an accomplished action. In extract 12,13, 14 and 15, the speaker employs the use of the first person plural pronoun we in his statements. This implies that the assertive in these extracts have to do with a group of individuals, which are the members of the PDP. The total percentage of assertives is $52.3 \%$.

Directives: As earlier stated a directive speech act attempts to get the addressee to do something. The following in example 2 are extracts expressing the directive illocutionary act.

2. Extract 5: Although some people have expressed mixed feelings about the results announced by the Independent National Electoral Commission (INEC), I urge those who may feel aggrieved to follow due process based on our constitution and our electoral laws, in seeking redress.

Extract 16: We must stand together as a party and look to the future with renewed optimism.

The speaker in extract 5 puts up a request while in extract 16, the illocutionary act expressed is likened to a demand that is inevitable hence the use of the word "must". The directives in the concession speech constitute a total of $9.5 \%$ of the total speech.

Expressive: This kind of speech act expresses a psychological state such as thanking, apologizing, congratulating and welcoming. Instances of the expressive are shown in example 3 below; 
3.Extract 1: I thank you all for turning out en-masse for the March 28 general elections.

Extract 8: I congratulate all Nigerians for successfully going through the process of March $28^{\text {th }}$ general elections with commendable enthusiasm and commitment that was demonstrated nationwide.

Extract 9: I also commend the security services for their role in ensuring that the elections are mostly peaceful and violence free.

Extract 10: To my colleagues in the PDP, I thank you for your support.

Extract 17: I thank all Nigerians once again for the opportunity I was given to lead this country.

Extract 20: May God Almighty continue to bless the Federal Republic of Nigeria.

Extract 21: I thank you all

A total of seven (7) extracts representing $33.3 \%$ are expressives found in the concession speech. Extracts 1, 8, 9, $10,17,20$ and 21 represent paradigm cases of thanking while extract 8 is a case of congratulating.

Commissives: Utterance forms expressing this illocutionary act usually commit the speaker to some future action as shown in example 4

4.Extract 18: I will continue to do my best at the helm of national affairs until the end of my tenure. This utterance form constitutes $4.7 \%$ of the concession speech.

The percentages of the illocutionary acts expressed in our data are presented in figure 1. 


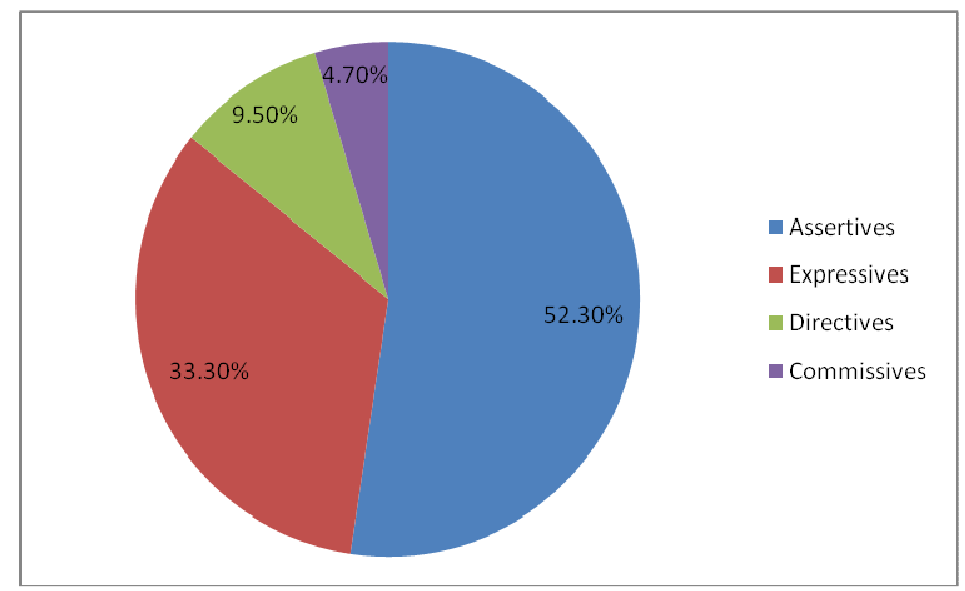

Fig 1: Percentages of illocutionary acts

\section{Findings and Conclusion}

Based on the result from the data analysis, there is a preponderance of assertives in the concession speech with a total percentage of 52.3. This is followed by the expressives with a proportion of $33.3 \%$. Directives and commissives account for $9.5 \%$ and $4.7 \%$ illocutionary acts respectively. There is however no extract in the concession speech that depicts the directive illocutionary act. We see the entire concession speech as an expression of the directive illocutionary acts in view of its contribution to stability in the country with regard to the peace that was sustained in the nation as a result of the President's concession.

In conclusion, the study attempts an analysis of the concession speech of President Goodluck Jonathan. It accounts for the various illocutionary acts expressed/performed in the speech. Our findings reveal the preponderance of assertives and expressives, lack of declaratives and a very small proportion of commissives expressed in the concession speech. Based on the findings, we 
can therefore deduce that there is a direct link between speech type and the illocutionary acts expressed in them.

Adaobi Ngozi Okoye \& Benjamin Ifeanyi Mmadike Department of Linguistics Nnamdi Azikiwe University, P.M.B. 5025, Awka, Nigeria.

\section{References}

Akinwotu, S. A. (2013). A speech act Analysis of the Acceptance of Nomination Speeches of Chief Obafemi Awolowo and Chief MKO Abiola. Dx.du.org/10.5430/elr.v2n/p43 (12 ${ }^{\text {th }}$ May, 2015)

Austin, J. L. (1962). How to Do Things With Words. London: Clarendon Press.

Bayram, F. (2010). Ideology and political discourse. A critical discourse analysis of Erdigan's Political speech. ARECLS, Vol 7. 23-40.

Hankansson, J. (2012). The use of personal pronouns in political speeches http.www.divaportal.org/smash.(12 ${ }^{\text {th }}$ May, 2015)

Levinson, S. C. (1983). Pragmatics - Cambridge: Cambridge University Press.

Mey Jacob L. (2001). Pragmatics: An introduction ( $2^{\text {nd }}$ ed) London: Blackwell Publishing Co. Saeed, J. I. (2003). Semantics. Oxford: Blackwell Publishing Limited.

Saeed, J. I.( 2007). Semantics .third edition. Oxford: Blackwell Publishing Limited.

Searle, J. R. (1969). Speech Acts. An Essay in the Philosophy of language. Cambridge: Cambridge University Press.

Waya David, T. N. O. (2013). A pragmatic analysis of Victory and inaugural speeches of President Goodluck: A measure of transformation and good governance in 
Nigeria. Innovare Journal of Social Sciences Vol (1) 2 $.17-21$

Yu. B., Kaufmann. S. and Diermeier. D. (2008). Classifying party affliation from political speech. Journal of Information Technology and Politics Vol 5. 33-43.

Concession speech, retrieved from http/daily post.ng/2015/Nigeria.decides full text of President Jonathan concession

Newspaper consulted.

The Daily Sun. www.sunnewsonline.com Friday, May 29, 2015. 